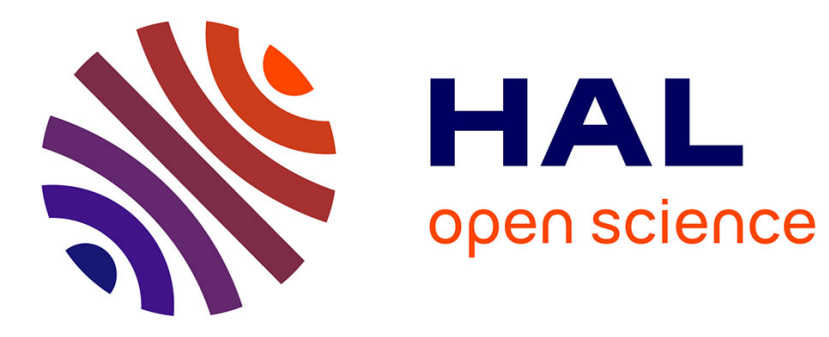

\title{
Biological activities of triterpenoids from Poraqueiba sericea stems
}

\author{
Ilhem Zebiri, Mohamed Haddad, Laurent Duca, Michel Sauvain, Lucie \\ Paloque, Billy Cabanillas, Elsa Rengifo, Jean-Bernard Behr, Laurence \\ Voutquenne-Nazabadioko
}

\section{To cite this version:}

Ilhem Zebiri, Mohamed Haddad, Laurent Duca, Michel Sauvain, Lucie Paloque, et al.. Biological activities of triterpenoids from Poraqueiba sericea stems. Natural Product Research, 2017, 31 (11), pp.1333-1338. 10.1080/14786419.2016.1241998 . ird-01382564

\section{HAL Id: ird-01382564 https://hal.ird.fr/ird-01382564}

Submitted on 17 Oct 2016

HAL is a multi-disciplinary open access archive for the deposit and dissemination of scientific research documents, whether they are published or not. The documents may come from teaching and research institutions in France or abroad, or from public or private research centers.
L'archive ouverte pluridisciplinaire HAL, est destinée au dépôt et à la diffusion de documents scientifiques de niveau recherche, publiés ou non, émanant des établissements d'enseignement et de recherche français ou étrangers, des laboratoires publics ou privés. 


\section{Biological activities of triterpenoids from Poraqueiba sericea stems}

Ilhem Zebiria , Mohamed Haddad ${ }^{\mathrm{b}}$, Laurent Ducac, Michel Sauvain ${ }^{\mathrm{b}}$, Lucie Paloque ${ }^{\mathrm{d}, \mathrm{e}}$, Nazabadioko ${ }^{a}$

anstitut de Chimie Moléculaire de Reims UMR 7312 CNRS, Université de Reims, Reims, France; bUMR 152 Pharma Dev, Université de Toulouse, IRD, UPS, France; 'Unité Matrice Extracellulaire et Dynamique Cellulaire (MEDyC), UMR CNRS 7369, Université de Reims, Reims, France; 'LCC (Laboratoire de Chimie de Coordination), CNRS, Toulouse, France; eUniversité de Toulouse, UPS, INPT, Toulouse, France; Instituto de Investigación de la

Amazonía Peruana (IIAP), lquitos, Perú

\section{ABSTRACT}

Eleven compounds were isolated from Poraqueiba sericea stems and identified as niga-ichigoside-F1 (1), trachelosperoside B1 (2), 4-epiniga-ichigoside (7), 19a-hydroxyasiatic acid (3), myrianthic acid (4), hyptatic acid (5), trachelosperogenin B (6), arjunolic acid (8), and trachelosperogenin $E(\mathbf{9})$, secologanoside $(\mathbf{1 0})$ and secoxyloganin (11). Compounds 1-11 were tested for their antileishmanial activities against Leishmania infantum promastigotes, 1-6 and 8-11 were tested for their cytotoxic activities on fibroblasts, 1-3, 5-6, 8-11 were evaluated for their anti-elastase and anti-acetylcholinesterase assays activities by a spectrophotometric method and $\mathbf{1 - 2 , 5}$ and $\mathbf{7 - 1 0}$ were tested using bioautography for their $\beta$-glucosidase. No antileishmanial activity was detected; compounds $\mathbf{1 , 2}$ and $\mathbf{1 1}$ showed a moderate cytotoxic activity with $\mathrm{IC}_{50} 17.7,20.5$ and $10.9 \mu \mathrm{g} / \mathrm{mL}$, respectively; compounds 2, 8, 9 and $\mathbf{1 0}$ gave a percentage of inhibition ranging from 13 to $16 \%$ (at $50 \mu \mathrm{g} / \mathrm{mL}$ ) and compounds 1 and 2 showed an inhibition zone on $\beta$-glucosidase and anti-acetylcholinesterase assays.

\section{ARTICLE HISTORY}

Received 10 May 2016

Accepted 14 September 2016

\section{KEYWORDS}

Poraqueiba sericea; Icacinaceae; triterpenes; secoiridoids 


\section{Introduction}

The genus Poraqueiba (Icacinaceae) is composed of three species: Poraqueiba sericea Tulp., Poraqueiba guianensis Aubl. and Poraqueiba paraensis Ducke, large trees growing exclusively in the Amazon. A literature survey showed very few reports on $P$. sericea Tulp, a tree grown initially by Native Americans and propagated by them in Bolivia, Brazil and Peru. This tree is cultivated in Peru for its edible fruit (named Umari in Peru), with a pleasant and a characteristic taste, consumed as such, or accompanied by cassava. It is also an ingredient in the soft drink composition called 'Cahuana' with tapioca starch. The oil extracted industrially from the mesocarp is a raw material for this region (food and frying). In industry, the Umari flour

10 replaces wheat flour in the production of adhesives for laminated wood. The only medicinal use concerns the leaves that are used by some tribes as infusion to treat themselves against dysentery (Huamán et al. 2001). Phytochemical investigation of Icacinaceae has resulted in the isolation of indolomonoterpenic alkaloids (Aiyama et al. 1988; Pirillo et al. 1995; Wu et al. 1995, 1996; Srinivas \& Das 2003; Khan et al. 2013), flavonoids (Manga et al. 2013), diterpenes

15 (On'okoko et al. 1985), pentacyclic triterpenes (Calderón et al. 2013) and monoterpene iridoids (Braga de Oliveira 1995). The phytochemical study of P. guianensis showed the presence of the triterpene icacinic acid, two emmotine derivatives (Braga de Oliveira 1995), one lignan (Goulart et al. 1994) and a secologanoside (Goulart 1983). Until now, there is no phytochemical or biological study reported for Poraqueiba sericea stems. Indeed, only the oil extracted

20 from the fruit has been the subject of study for the characterisation of these fatty acids (Silva 1997).

\section{Results and discussion}

The structures of the isolated compounds were determined mainly by means of extensive spectroscopic methods including (1D ( ${ }^{1} \mathrm{H}$ and ${ }^{13} \mathrm{C}$ NMR), 2D NMR (COSY, ROESY, HSQC, and

$25 \mathrm{HMBC}$ ) and HR-ESIMS, and by comparison with reported data in the related literature. They are identified as: niga-ichigoside-F1 (1) (Bowen-Forbes et al. 2009), trachelosperoside B1 (2) (Bowen-Forbes et al. 2009), 19a-hydroxyasiatic acid (3) (Bowen-Forbes et al. 2009), myrianthic acid (4) (Hirai et al. 2000), hyptatic acid (5) (Bowen-Forbes et al. 2009), trachelosperogenin B (6) (Abe \& Yamauchi 1987), 4-epi-niga-ichigoside (7) and arjunolic acid (8) (Bowen-Forbes

30 et al. 2009), trachelosperogenin E (9) (Nasser et al. 2006), secologanoside (10) and secoxyloganin (11) (Calis \& Sticher 1984) (Figure 1). Compounds 1-11 were tested for their antileishmanial activity against Leishmania infantum promastigotes but no activity was detected (at 100, 10, 1 and $0.1 \mu \mathrm{g} / \mathrm{mL}$ ) (Sosa et al. 2016). Compounds $\mathbf{1 - 6}$ and 8-11 were also tested (concentration range of $10,7.5,5,2.5$ and $1 \mu \mathrm{g} / \mathrm{mL}$ ) for their cytotoxicity against human

35 dermal fibroblasts using a MTT assay. Compounds $\mathbf{1 , 2}$ and $\mathbf{1 1}$ showed a very moderate activity with $19.5,24.6$ and $22.4 \%$ cell death, respectively, at $10 \mathrm{mg} / \mathrm{mL}$ (Table 1 ) and $\mathrm{IC}_{50}$ values of $17.7,20.5$ and $10.9 \mu \mathrm{g} / \mathrm{mL}$, respectively. The positive control, $\alpha$-hederin, possessedg $71.3 \%$ cell death at the same concentration and an $\mathrm{IC}_{50}$ of $3.5 \mu \mathrm{g} / \mathrm{mL}$. Compounds $\mathbf{1 - 3}, \mathbf{5 - 6}$, 8-11 were evaluated for their anti-elastase activity and four compounds $(\mathbf{2}, \mathbf{8 - 1 0})$ gave a low inhibition percentage ranging from 13 to $16 \%$ at $50 \mu \mathrm{g} / \mathrm{mL}$ (Table 1), twofold less active than ursolic acid used as a standard (31\% inhibition) corresponding to $\mathrm{IC}_{50}$ values of 24.5 , $35.9,31.0$ and $42.0 \mu \mathrm{M}$, respectively (10.5 $\mu \mathrm{M}$ for ursolic acid). These compounds should be tested on other elastases because the activities of these enzymes deferred based on their 


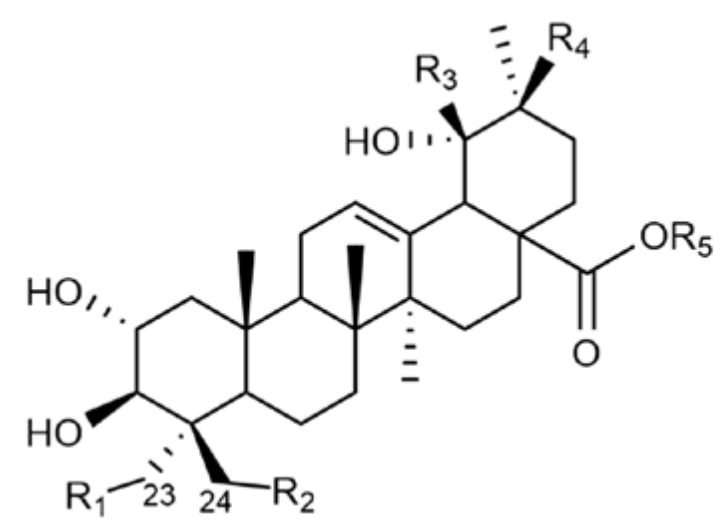

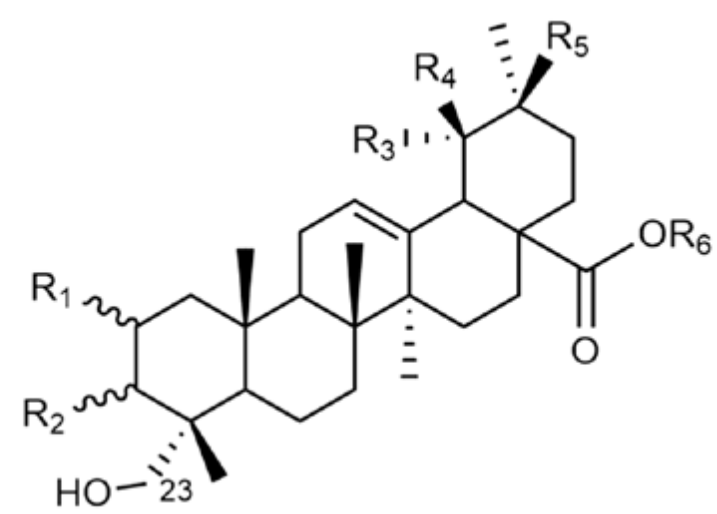

\begin{tabular}{|c|c|c|c|c|c|c|c|c|c|c|c|c|c|}
\hline & $R_{1}$ & $\mathbf{R}_{\mathbf{2}}$ & $\mathbf{R}_{3}$ & $\mathbf{R}_{4}$ & $\mathbf{R}_{5}$ & & & $R_{1}$ & $\mathbf{R}_{2}$ & $\mathbf{R}_{\mathbf{3}}$ & $\mathbf{R}_{\mathbf{4}}$ & $R_{5}$ & $\mathbf{R}_{6}$ \\
\hline 2 & $\mathrm{OH}$ & $\mathrm{OH}$ & $\mathrm{CH}_{3}$ & $\mathrm{H}$ & $\beta$-D-Glc & & 1 & ๘৩Н & $\mathrm{BOH}$ & $\mathrm{OH}$ & $\mathrm{CH}_{3}$ & $\mathrm{H}$ & $\beta$-D-GIc \\
\hline 6 & $\mathrm{OH}$ & $\mathrm{OH}$ & $\mathrm{CH}_{3}$ & $\mathrm{H}$ & $\mathrm{H}$ & & & & $\mathrm{BOH}$ & $\mathrm{OH}$ & & $\mathrm{H}$ & \\
\hline 5 & $\mathrm{H}$ & $\mathrm{OH}$ & $\mathrm{CH}_{3}$ & $\mathrm{H}$ & $\mathrm{H}$ & no & & ne & BOH & H & $\mathrm{CH}_{3}$ & $\mathrm{H}$ & $\mathrm{H}$ \\
\hline 7 & H & $\mathrm{OH}$ & $\mathrm{CH}_{3}$ & $\mathrm{H}$ & B-D-Glc ${ }^{1}$ & lour & 4 & $\mathrm{aOH}$ & $\alpha \mathrm{OH}$ & $\mathrm{OH}$ & $\mathrm{CH}_{3}$ & $\mathrm{H}$ & $\mathrm{H}$ \\
\hline 9 & $\mathrm{OH}$ & $\mathrm{OH}$ & $\mathrm{H}$ & $\mathrm{CH}_{3}$ & H & & 8 & $\alpha \mathrm{OH}$ & $\alpha \mathrm{OH}$ & H & $\mathrm{H}$ & $\mathrm{CH}_{3}$ & $\mathrm{H}$ \\
\hline
\end{tabular}<smiles>[R]OC(=O)C1=COC(O[C@@H]2O[C@H](CO)[C@@H](O)[C@H](O)[C@H]2O)C(C=C)C1CC(=O)O</smiles>

Figure 1. Chemical structures of compounds 1-11.

origin. Therefore, we could have a greater activity on other elastase types. Compounds 1-2, 5 and 7-10 were tested using bioautography (Camag, Switzerland) for their $\beta$-glucosidase and anti-acetylcholinesterase activities at $1 \mathrm{mg} / \mathrm{mL}$ (application of $2 \mu \mathrm{L}$ in $8 \mathrm{~mm}$ band length). Only compounds $\mathbf{1}$ and $\mathbf{2}$ showed an inhibition zone on the $\beta$-glucosidase assay (Substrate: 2-naphthyl- $\beta$-glucopyranoside) with an inhibition zone of 11 and $7 \mathrm{~mm}$ respectively whereas the positive control, acarbose, showed an inhibition zone of $5 \mathrm{~mm}$ only. To verify the detected activity, we used other $\beta$ and $\alpha$-glucosidase $(0.013 \mathrm{U} / \mathrm{mL})$ tests in vitro for compounds 1 and 2 at $500 \mu \mathrm{g} / \mathrm{mL}$ but no activity was revealed by a spectrometrical quantification of the released $p$-nitrophenolate at $410 \mathrm{~nm}$. This suggests that the activity detected on bioautography may be due to an excessive concentration and/or to a reaction of the two saponins with the substrate. The anti-acetylcholinesterase $(6.66 \mathrm{U} / \mathrm{mL})$ assay was performed using Fast Blue B salt as reagent, 1-naphthyl acetate as substrate and convallatoxin as positive control. Compounds 1 and $\mathbf{2}$ showed also an inhibition zone of 0.8 and $0.5 \mathrm{~mm}$, respectively, and $0.4 \mathrm{~mm}$ for convallatoxin. Till then we could not verify this activity by in vitro tests because we did not have all the required elements. 
$4 \Leftrightarrow$ I. ZEBIRI ET AL.

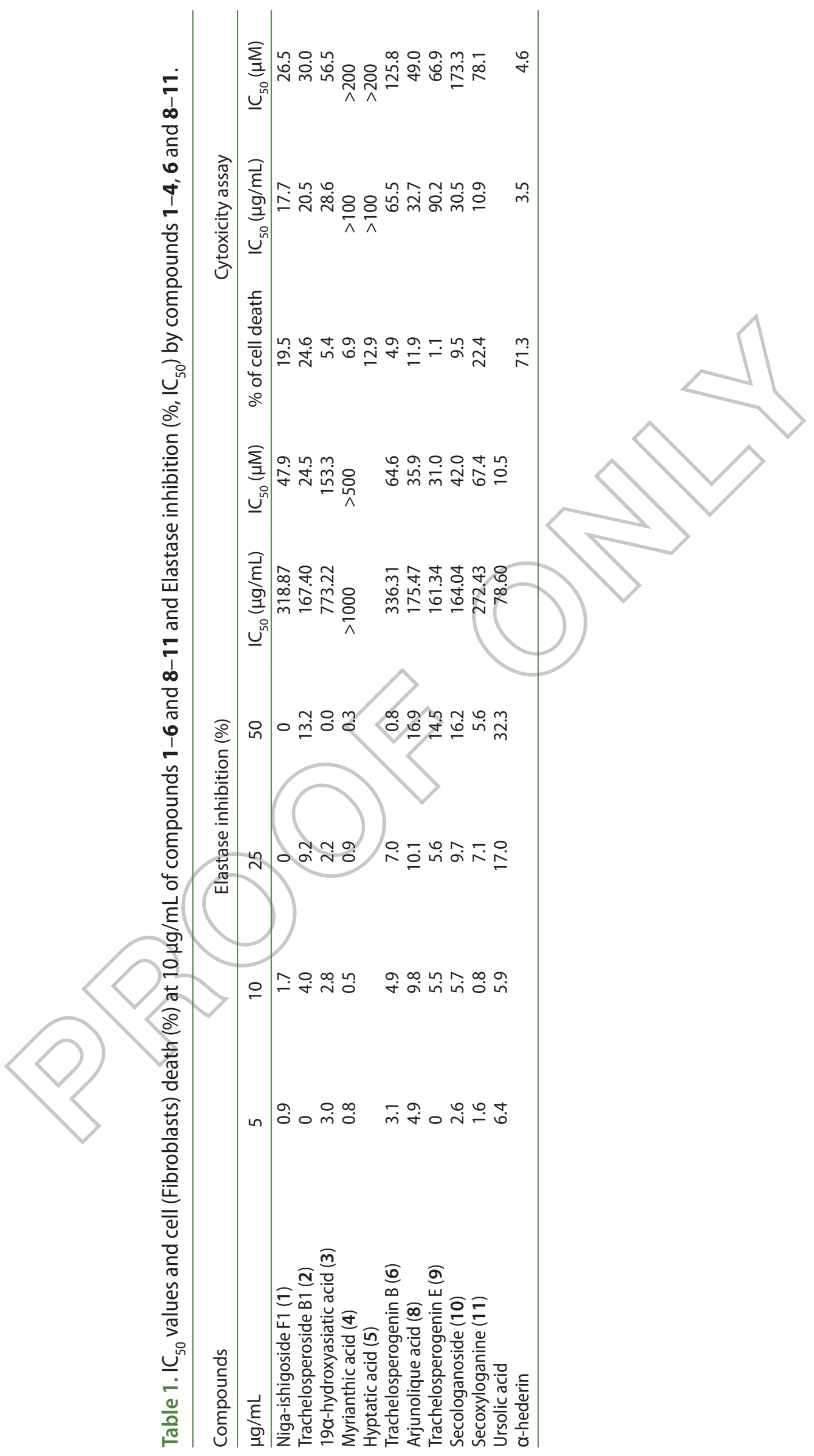




\section{Experimental}

See Supplementary material.

\section{Conclusion}

In this study, three triterpenoids saponins $(\mathbf{1}, \mathbf{2}, \mathbf{7})$, six triterpenes $(\mathbf{3}-\mathbf{6}, \mathbf{8}-\mathbf{9})$, and two secoiridoids (10-11) were isolated and identified from $P$. sericea. Except for the two secologanosides (10-11) (Braga de Oliveira 1995), this is the first report of these triterpenoids in the genus Poraqueiba and the Icacinaceae family. Compounds $\mathbf{1 0}$ and $\mathbf{1 1}$ were considered as chemotaxonomic markers of Icacinaceae species. The isolated compounds was evaluated for several biological activities to valorise our phytochemical study. Compound 1, 2 and 10 showed moderate cytotoxicity on fibroblasts ( IC $_{50}: 17.7,20.5$ and $10.9 \mu \mathrm{g} / \mathrm{mL}$ respectively) and compounds $\mathbf{2}, \mathbf{8}, \mathbf{9}$ and $\mathbf{1 0}$ showed low antielastase activity with $\mathrm{IC}_{50}$ of 24.5, 35.9, 31.0 and $42.0 \mu \mathrm{M}$, respectively. On bioautography, compounds 1 and $\mathbf{2}$ showed significant inhibition zones for anti- $\beta$-glucosidase and anti-acetylcholinesterase activities. Compounds 1-11 did not show any antileishmanial activity. This phytochemical and biological investigation helps us to extend the knowledge about the constituents of the unstudied Poraqueiba sericea plant.

\section{Acknowledgements}

The authors wish to express thanks to French Minister of Higher Education and Scientific Research for financial support and CNRS, Conseil Regional Champagne Ardenne, Conseil General de la Marne, Ministry of Higher Education and Research (MESR) and EU-programme FEDER to the PIAneT CPER project is gratefully acknowledged.

\section{Disclosure statement}

No potential conflict of interest was reported by the authors.

\section{References}

Abe F, Yamauchi T. 1987. Trachelosperosides, glycosides of 19a-hydroxyursane-type triterpenoids from Trachelospermum asiaticum (Trachelospermum. III). Chem Pharm Bull. 35:1748-1754.

Aiyama R, Hisako N, Kenichiro N, Chigiru S, Seigo S. 1988. A camptothecin derivative from Nothapodytes foetida. Phytochemistry. 27:3663-3664.

Bowen-Forbes CS, Mulabagal V, Liu Y, Nair MG. 2009. Ursolic acid analogues: non-phenolic functional food components in Jamaican raspberry fruits. Food Chem. 116:633-637.

Braga de Oliveira A. 1995. Terpenoids from Amazonian Icacinaceae, Vol. 588. Chemistry of the Amazon, Chapter 10; p. 99-115.

Calderón Al, Hodel A, Craig E, Gupta MP. 2013. Triterpenes and fatty acids from Discophora guianensis identified by GC-MS. Biochem Syst Ecol. 50:16-18.

Calis I, Sticher O. 1984. Secoiridoid glucosides from Lonicera periclymenum. Phytochemistry. 23:25392540.

Goulart MOF. 1983. Estudo químico de quatro espécies vegetais da Amazônia e eletroquímica de emotinas [Ph.D Tesis]. Universidade Federal de Minas Gerais Belo Horizente.

Goulart MOF, Sant'ana AEG, Alves RJ, de Souza Filho JD, Maia JGS, de Oliveira GG, de Oliveira LB. 1994. Icacinic acid, a triterpenoid from Poraqueiba guianensis. Phytochemistry. 37:1139-1142. 
Hirai N, Sugie M, Wada M, Lahlou EH, Kamo T, Yoshida R, Tsuda M, Ohigashi H. 2000. Triterpene phytoalexins from strawberry fruit. Biosci Biotechnol Biochem. 64:1707-1712.

Huamán PRO, Vargas EBA, Garazatua JF. 2001. Aprovechamiento integral del umarí (Poraqueiba sericea Tulasne) en la industria de alimentos. Rev Amaz Invest Alim. 1:30-37.

Khan N, Tamboli ET, Sharma VK, Kumar S. 2013. Phytochemical and pharmacological aspects of Nothapodytes nimmoniana. An overview. Herba Pol. 59:53-56.

Manga A, Gassama A, Sy GY, Bassene E, Lavaud C. 2013. Structural determination of news flavones C-glycosides and trans ( $\mathrm{S}, \mathrm{E})-(-)$ clovamide isolated from Icacina senegalensis Juss leaves (Icacinaceae). J. Soc. Ouest-Afr. Chim. 17:15-27.

Nasser ALM, Mazzolin LP, Hiruma-Lima CA, Santos LS, Eberlin MN, Souza Brito ARM, Vilegas W. 2006. Preparative droplet counter-current chromatography for the separation of the new nor-secotriterpene and pentacyclic triterpenoids from Qualea parviflora. Chromatographia. 64:695-699.

On'okoko P, Vanhaelen M, Vanhaelen-Fastré R, Declercq JP, Van Meerssche M. 1985. The constitution of icacinol, a new diterpene with a pimarane skeleton from /cacina claessensis. Tetrahedron. 41:745-748.

Pirillo A, Verotta L, Gariboldi P, Torregiani E, Bombardelli E. 1995. Constituents of Nothapodytes foetida. J Chem Soc Perkin Trans. 1:583-587.

Silva NAC. 1997. Characterization of crude, neutro and blenched oil from pulp and peel of jungle fruit Paraqueiba-sericea-Tulasne umari. Grasas Aceites. 48:11-16.

Sosa AM, AmayaS, Salamanca CapusiriE, GilabertM,Bardón A, GiménezA,Vera NR, BorkoskySA.2016. Active sesquiterpene lactones against Leishmania amazonensis and Leishmania braziliensis. Nat Prod Res. doi: 10.1080/14786419.2015.1126260.

Srinivas KVNS, Das B. 2003. 9-Methoxy-20-O-acetylcamptothecin, a minor new alkaloid from Nothapodites foetida. Biochem Syst Ecol. 31:85-87.

Wu TS, Leu YL, Hsu HC, Ou LF, Chen CC, Chen CF, Ou JC, Wu YC. 1995. Constituents and cytotoxic principles of Nothapodytes foetida. Phytochemistry. 39:383-385.

Wu TS, Leu YL, Hsu HC, Ou LF, Chen CC, Chen CF, Ou JC, Wu YC. 1996. Nothapodytes A and B from Nothapodytes foetida. Phytochemistry. 42:907-908.

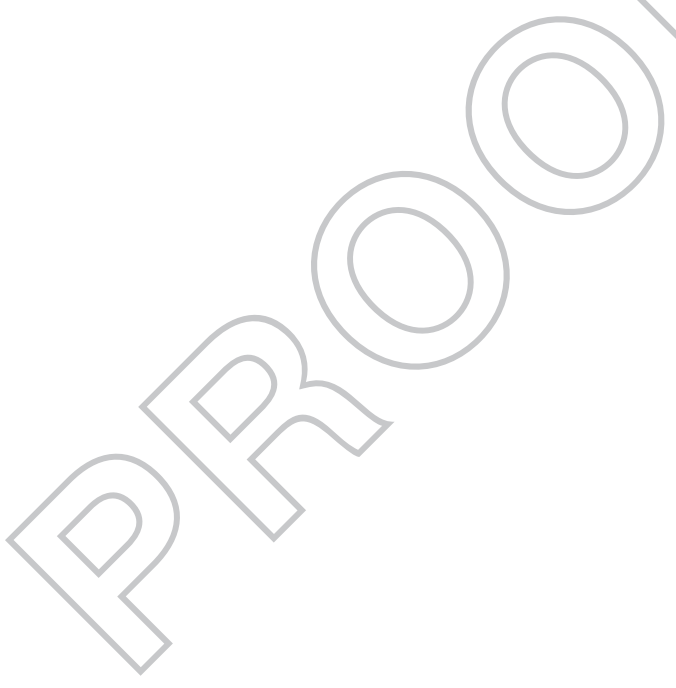

